\title{
A giant omphalocele in a preterm infant: the conservative approach
}

\author{
Felicia Drack, ${ }^{1}$ Alexander Mack, ${ }^{2}$ Walter Kistler, ${ }^{2}$ Bjarte Rogdo ${ }^{1}$
}

'Paediatric and Neonatal Intensive Care Unit, Children's Hospital of Eastern Switzerland, St Gallen, Switzerland

${ }^{2}$ Department of Surgery, Children's Hospital of Eastern Switzerland, St Gallen, Switzerland

\section{Correspondence to}

Dr Bjarte Rogdo,

bjarte.rogdo@kispisg.ch

Accepted 10 November 2014

\section{DESCRIPTION}

A routine antenatal ultrasound scan in the first trimester revealed a large omphalocele mainly occupied by liver in a female infant. Owing to preterm labour she was delivered by caesarean section at $29^{+4}$ weeks of gestation with a birth weight of $1450 \mathrm{~g}$. No other malformations were present and her karyotype was normal.

The neonatal period was complicated by severe respiratory distress with pulmonary hypertension requiring prolonged high-frequency ventilation and inhaled nitric oxide. The infant developed bilateral grade 2 intraventricular haemorrhages. A haemodynamically significant ductus arteriosus was closed surgically. Owing to these complications, primary closure of the $4 \times 4 \mathrm{~cm}$ large omphalocele (figure 1) was initially not feasible. Palliative care was considered, but was not an acceptable option to the parents. Hence conservative management was chosen aiming for delayed closure when the patient was stable enough.

Initial topical treatment with hydrofibre dressing with silver was stopped after 2 weeks, as concerns relating to silver toxicity have been described in the literature. ${ }^{1}$ Our patient had no clinical signs of silver toxicity and epithelialisation continued to progress well with hydrofibre dressings without silver. Complete epithelialisation was achieved at 4 months of age (figure 2). Final surgical repair 1 month later was uneventful and the patient could be extubated on the second postoperative day.

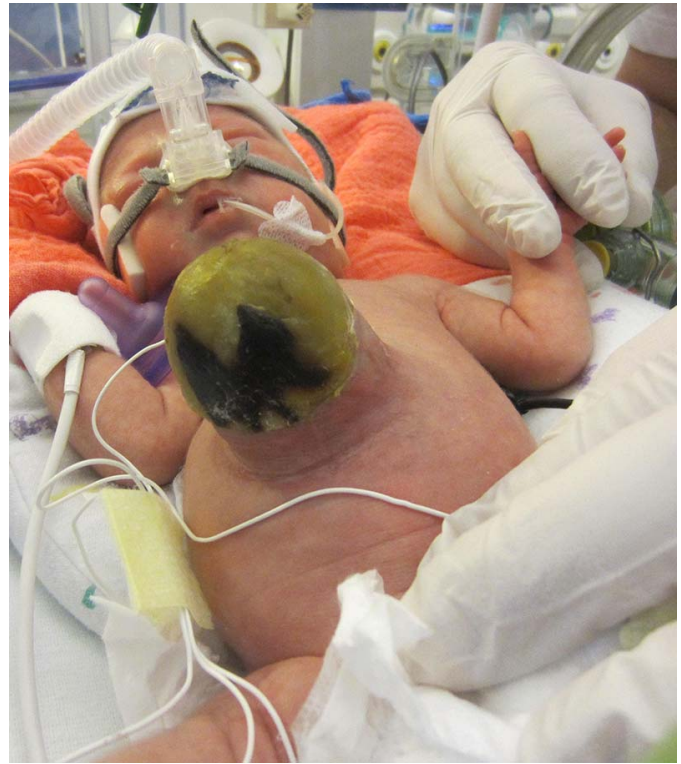

Figure 1 Omphalocele 4 weeks after birth.

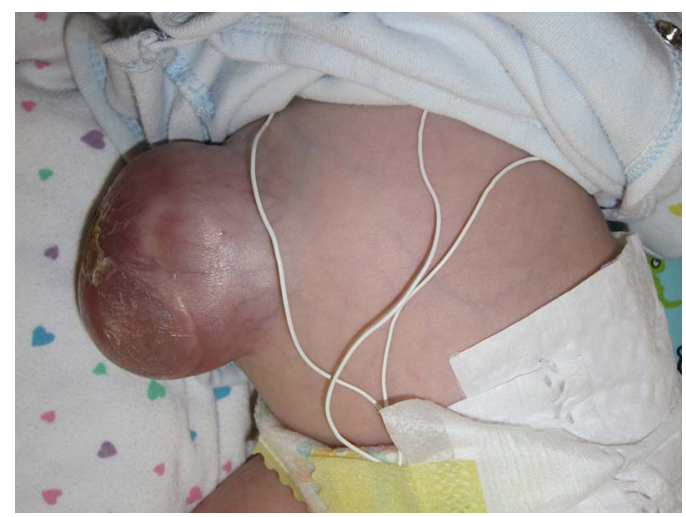

Figure 2 Omphalocele completely epithelialised at 4 months of age.

An abdominal wall midline defect with a diameter greater than $4-6 \mathrm{~cm}$ and containing liver is usually considered to be a giant omphalocele (GO). However, no universal consensus exists on the definition. GO is associated with pulmonary hypoplasia and carries a high mortality risk. Delayed closure of a GO is a well-known alternative management technique in neonates who are either too unstable or with a defect considered too large for primary closure. $^{2}$ There is a paucity of reports describing a successful outcome with a delayed approach in very preterm infants. Active treatment of GOs in this population is often deemed futile as chances of survival without major morbidity are low. ${ }^{3}$

This case demonstrates the possibility of a satisfactory outcome in a very low birthweight infant with a GO undergoing delayed closure (figure 3). However, it must be emphasised that the clinical course was highly complicated and hospitalisation prolonged. Following surgical repair, there were

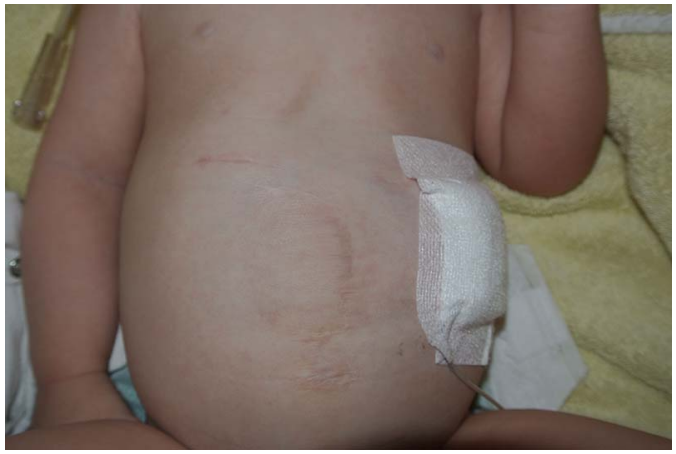

Figure 3 The result a few months after secondary closure of the omphalocele. A transabdominal jejunal catheter in place due to feeding difficulties. 


\section{Learning points}

In very low birthweight infants, primary closure of even a small-sized to mid-sized omphalocele might not be feasible in the first few weeks of life due to complications of prematurity.

- Conservative treatment with secondary delayed closure can be a successful alternative to primary closure or staged repair in these infants.

repeated episodes of severe cardiopulmonary compromise with readmissions to the intensive care unit.

Our patient was discharged at a corrected age of 10 months. At this time she showed severe delays in gross motor and moderate delays in fine motor development. The follow-up examination at a corrected age of 15 months revealed only mild neurodevelopmental delay owing to great improvements in gross and fine motor development, with cognitive test results within normal limits for the infant's age.

Contributors FD and BR wrote the manuscript. FD, BR and the patient's parents provided the pictures. AM revised the manuscript. AM and WK were the surgeons in charge of the case.

Competing interests None.

Patient consent Obtained.

Provenance and peer review Not commissioned; externally peer reviewed.

\section{REFERENCES}

1 Lewis N, Kolimarala V, Lander A. Conservative management of exomphalos major with silver dressings: are they safe? J Pediatr Surg 2010;45:2438-9.

2 Lee SL, Beyer TD, Kim SS, et al. Initial nonoperative management and delayed closure for treatment of giant omphaloceles. J Pediatr Surg 2006:41:1846-9.

3 Feltman D, Stokes T, Kett J, et al. Is treatment futile for an extremely premature infant with giant omphalocele? Pediatrics 2014;133:123-8.

Copyright 2014 BMJ Publishing Group. All rights reserved. For permission to reuse any of this content visit http://group.bmj.com/group/rights-licensing/permissions.

BMJ Case Report Fellows may re-use this article for personal use and teaching without any further permission.

Become a Fellow of BMJ Case Reports today and you can:

- Submit as many cases as you like

- Enjoy fast sympathetic peer review and rapid publication of accepted articles

- Access all the published articles

- Re-use any of the published material for personal use and teaching without further permission

For information on Institutional Fellowships contact consortiasales@bmjgroup.com

Visit casereports.bmj.com for more articles like this and to become a Fellow 